Jusmal Ilmial

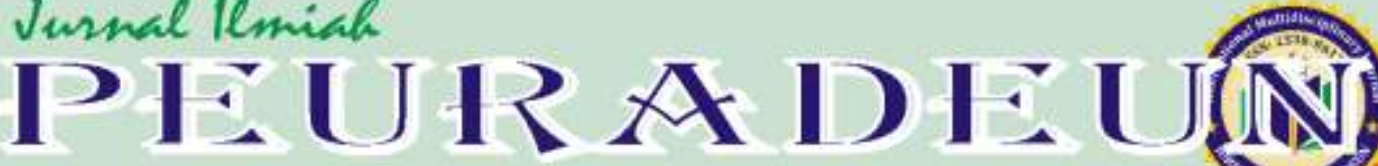

Media Kajian Ilmial Sosial, Politik, Heatum, Agama dan Budaya

Americanizing Islam As The Price of Assimilation

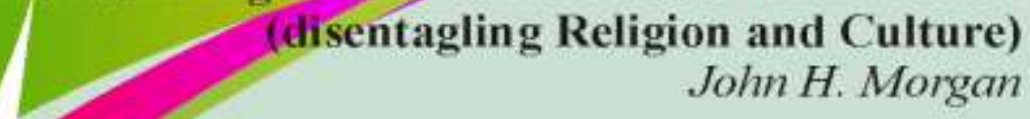

The Ritual of Marriage

(An Ethographic Study in West Labuhan Haji-south Aceh)

Abdul Manan

Paradigma Holisme Hegelian dan Kritik Atas Liberalisme

Otto Gusti Madung

Kelembagaan Wilayat Al-Hisbah dalam Konteks Penerapan Syariat Islam di Provinsi Aceh Muhibbuthabry

Distorsi Terhadap Islam: Analisis Pemberitaan Media Barat Jasafat

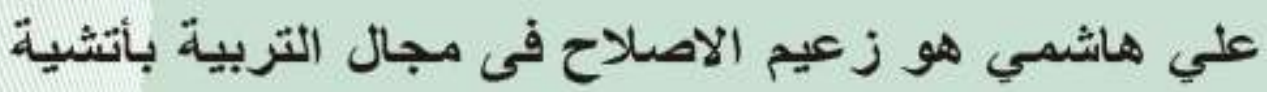
Syabuddin Gade

أصول التفسير عند عبد الله بن عمر رضي الله عنهما في تفسير الثرآن Andri Nirwana AN

Thomson Reuters: RID-F-6135-2014 ISI Impact Factor Value 2013 ICR: 0.217 Google Scholar Index-h:3, in $0: 3$ $\oint_{\text {Copernicus Publications }}^{\text {Conmathe }}$

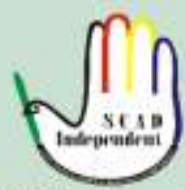

SCAI Independent IAO Accreditation 4-8362/387/1AO/2014 


\title{
ISLAMIC STUDIES DALAM PENDEKATAN MULTIDISIPLINER (Suatu Kajian Gradual Menuju Paradigma Global)
}

\author{
Tabrani. ZA $\mathbf{Z A}^{1}$
}

\begin{abstract}
Education is a vicious circle phenomenon, which we can not go out with just rely on one approach is diachronic. Moreover, the Islamic education that still has a serious problem faced by most of the drafter of Islamic education is the ability to understand the low level of Islamic education as a "science" and Islamic education as an "educational institution". The existence of Islamic education and also should be able to provide a solution to various problems and development needs of the people. Thus, finding new formats in the dynamics of Islamic education is a necessity to help humanity. Here the author tries to describe Islamic education with a combination approach that the synchronic diachronic history of the social sciences, namely sociology and anthropology to bring its characteristics and also the characters. As well as the last author tries to provide an alternative-solution-based approach should be used to study the future of Islamic education.

$$
\begin{aligned}
& \text { مستخلص } \\
& \text { التعليم هو ظاهرة الحلقة المفرغة، التي لا نستطيح الخخروج مع الاعتماد فقط على فه واحد هو } \\
& \text { ديكرونك (diachronic). وعلاوة على ذلك، فإن التربية الإسلامية التي لا تزال للديها هشكلة } \\
& \text { خطيرة تو أجهوا هعظم الصياغة التربية الإسلامية هو القلدرة على فهم هستوى منخفض من }
\end{aligned}
$$

1 Dosen tetap pada Fakultas Tarbiyah Universitas Serambi Mekkah Banda Aceh. Peneliti pada SCAD Independent, juga merupakan salah satu anggota peneliti pada Thomson Reuters, Philadelphia, USA dengan RID: F-6709-2014, member of researcher in Orchid, ID: 0000-0003-1014-3841. Menyelesaikan Magister dalam ilmu Studi Islam pada Universitas Islam Indonesia (UII) Yogyakarta. Aktif sebagai Sekretaris Jenderal Gerakan Intelektual Se-Aceh (GISA) 2012-2017 dan Anggota Departemen Advokasi pada Forum Pelopor Perdamaian Aceh (FP2A) Kementerian Sosial RI. E-mail: tabrani_aceh@ymail.com
\end{abstract}


Vol. II, No. 02, Mei 2014

$$
\begin{aligned}
& \text { لتعليم الإسلامي بأنه" العلم "والتربية الإسلامية باعتبارها" مؤسسة تعليمية . "وجود التربية } \\
& \text { الإسلادية وأيضا يجب أن تكون قادرة على توفير مل لمختلف المشاكل واحتياجات التنمية } \\
& \text { لشعب .و بالتالي، وإيماد صيغ جلديدة ي ديناميات التربية الإسلامية هو ضرورة للمساعدة } \\
& \text { الإنسانية .هنا يكاول المؤلف في وصف التربية الإسلامية هع فه الجممع أن تاريخ ديكرونك فيك } \\
& \text { (diachronic) } \\
& \text { خصائصه وأيضا حرفا مو كذلك يماول المؤلف الماضي لتقلديم وينبغي أن تستخدام هجا بديلا } \\
& \text { المستناة إلى حل للمراسة مستقبل التعليم الإسلاني. }
\end{aligned}
$$

Keywords: Islamic Studies, Multidisciplinary Approach, Islamic Education, Holistic-Integrative

\section{A. Pendahuluan}

Realitas sebuah perubahan harus disikapi secara flexibility, karena itu merupakan suatu hukum alam dan juga merupakan "realitas keagungan Tuhan". Perubahan yang terus bergulir akan mengubah perspektif yang memandang dunia ini penuh keteraturan menjadi dunia yang penuh tantangan untuk mencapai ketenangan. Hal tersebut diindikasikan dengan berubahnya fase newtonian menjadi fase quantum dan economical capital menjadi intellectual capital. Perubahan-perubahan ini juga akan berimbas pada realitas konsumtif menuju realitas reinventor bahkan juga membangun realitas kompetitif-regional menjadi realitas kompetitif-global.

Perubahan tersebut akan membawa rancangan mekanisme atau aturan tersendiri yang akan menjadi suatu sistem nilai-nilai (systems of values) yang "luhur" dan juga menjadi pegangan setiap individu, keluarga, atau kelompok komunitas atau masyarakat tertentu, atau pada gilirannya bangsa dan negara tertentu. Hal ini pernah disinyalir oleh John Naisbitt dan Patricia Aburdence, futurolog suami istri terkemuka dunia, pada era dekade tahun 90an yang meramalkan bahwa abad 21 merupakan era baru (Imam Tholkhah dan Ahmad Barizi, 2004: 1). Ternyata ramalan dua futurolog dunia tersebut menjadi "kebenaran tak terbantahkan" bahwa perubahan realitas/era telah menjadi era dengan nilai baru. Suatu era di mana yang menjadi bagian global dalam kehidupan manusia adalah fenomena ekonomi global dan informasi. 
Bahkan pola relasi menggantikan hirarki sebagai modal utama untuk menyelesaikan semua problema kehidupan.

Dunia pendidikan juga tidak akan bisa lepas dari unsur perubahan. Maka sangat wajar jika dari perspektif filosofis, pembelajaran (learning) oleh Peter M. Senge (1994: 23) diartikan dengan study and practice constanly. Karena hal tersebut tidak lepas dari hukum alam yang akan merongrong pendidikan untuk menapak tangga yang lebih tinggi dan juga tuntut untuk menempatkan eksistensinya sesuai dengan tuntutan realitas. Tetapi walaupun dalam realitas tersebut terus mengalir perubahan-perubahan yang menuntut hal lain pada dunia pendidikan dan juga pada manusia, tetapi curiosity (sifat ingin tahu) harus tetap menjadi spirit dalam hidup manusia. Artinya kedinamisan realitas harus diimbangi dengan gerakan konstruktif-solutif. Meminjam statemen dari Russel (dalam Abdurrahman Mas'ud, 2002: 9) bahwa "it is better to be clearly wrong than vaguely right", maka sikap seperti itu seharusnya yang dibangun dalam tatanan kehidupan dalam lingkaran pendidikan dan manusia sendiri untuk memunculkan suatu sikap optimistik-selektif dan juga untuk menumbuhkan spirit dalam mencari problem soulving untuk menjawab tuntutan realitas terhadap pendidikan (way of life long education).

Esensi dari pendidikan itu sendiri sebenarnya adalah pengalihan (transmisi) kebudayaan (ilmu pengetahuan, teknologi, ide-ide, etika dan nilainilai spiritual serta estetika) dari generasi yang lebih tua kepada generasi yang lebih muda dalam setiap masyarakat atau bangsa. ${ }^{2}$ Proses transmisi ini diharapkan mampu untuk menjadi nilai hidup dalam mempersiapkan Sumber Daya Manusia (Human Resources) generasi berikutnya untuk menghadapi perubahan era baru.

Oleh sebab itu dalam tataran ini, sejarah pendidikan mempunyai sejarah yang usianya sesuai dengan alur usia masyarakat pelakunya sendiri, sejak dari pendidikan informal dalam keluarga, sampai kepada pendidikan formal dan non-formal dalam masyarakat agraris maupun industri. Artinya,

${ }^{2}$ Sedangkan John Dewey, seperti yang dikutip oleh A. Malik Fadjar mengatakan bahwa pendidikan merupakan suatu kebutuhan hidup (a necessity of life), sebagai bimbingan ( $a$ direction), sebagai sarana pertumbuhan (a growt), yang mempersiapkan dan membukakan serta membentuk disiplin hidup. Pendidikan mengandung misi keseluruhan aspek kebutuhan hidup serta perubahan-perubahan terjadi (lihat dalam A. Malik Fadjar, 1998: 54). 
Vol. II, No. 02, Mei 2014

rentang waktu yang dilalui oleh pendidikan sebagai bagian dari sejarah sosial kemanusiaan mempunyai hubungan erat dengan peradaban manusia itu sendiri dan juga rentang waktu perjalanan manusia di muka bumi. Dengan demikian, seperti yang diungkapkan oleh Edward Hallett Carr, yang dikutip oleh Djoko Soerjo (2007: 26), bahwa sejarah (pendidikan) merupakan suatu dialog tiada akhir antara masa kini dan masa lalu.

Sejarah pendidikan selama ini masih menggunakan pendekatan konvensional yang umumnya bersifat diakronis, yang kajiannya berpusat pada sejarah dari ide-ide dan tokoh pemikir besar dalam pendidikan, atau sejarah dan sistem pendidikan dan juga lembaga-lembaga, atau sejarah perundangundangan dan kebijakan umum dalam bidang pendidikan. Pendekatan yang umumnya bersifat diakronis ini dianggap statis, sempit serta terlalu melihat ke dalam. Seiring dengan perkembangan zaman dan kemajuan dalam pendidikan beserta segala macam masalah yang timbul atau ditimbulkannya, penanganan serta pendekatan baru dalam sejarah pendidikan dirasakan sebagai kebutuhan yang mendesak oleh para sejarawan pendidikan.

Para pemerhati pendidikan melihat hubungan timbal balik antara pendidikan dan masyarakat; antara penyelenggara pendidikan dengan pemerintah sebagai representasi bangsa dan negara yang merumuskan kebijakan (policy) umum bagi pendidikan nasional. Produk (output) dari pendidikan menimbulkan mobilitas sosial (vertikal maupun horizontal); masalah-masalah yang timbul dalam pendidikan yang dampak-dampaknya (positif ataupun negatif) dirasakan terutama oleh masyarakat sebagai konsumen pendidikan.

Fenomena pendidikan tersebut di atas merupakan lingkaran setan, yang kita tidak bisa keluar dengan hanya mengandalkan satu pendekatan yang bersifat diakronis. Apalagi dalam pendidikan Islam yang sampai sekarang masih mempunyai masalah serius yang dihadapi oleh sebagian besar konseptor pendidikan Islam yaitu rendahnya tingkat kemampuan memahami pendidikan Islam sebagai suatu "ilmu" dan pendidikan Islam sebagai suatu "lembaga pendidikan".

Harus diakui, memahami pendidikan Islam sebagai suatu sistem ilmu pengetahuan dan membedakan pengertiannya dengan pendidikan Islam sebagai suatu lembaga pendidikan tidak semudah seperti memahami objek 'ilmu' bersifat abstrak, sedangkan 'lembaga pendidikan' bersifat konkret.

Sehubungan dengan hal di atas pendekatan sejarah pendidikan (Islam) baru tidak cukup dengan cara-cara diakronis saja. Perlu ada pendekatan 
metodologis yang baru yaitu dengan pendekatan interdisipliner. Dalam pendekatan interdisipliner dilakukan kombinasi pendekatan diakronis sejarah dengan sinkronis ilmu-ilmu sosial. Pada era sekarang ini, ilmu-ilmu sosial tertentu seperti antropologi, sosiologi, dan politik telah memasuki "perbatasan" (sejarah) pendidikan dengan "ilmu-ilmu terapan" yang disebut antropologi pendidikan, sosiologi pendidikan, dan politik pendidikan. Dalam pendekatan ini dimanfaatkan secara optimal dan maksimal hubungan dialogis "simbiosis mutualistis" antara sejarah dengan ilmu-ilmu sosial.

Oleh sebab itu, penulis mencoba untuk mendeskripsikan pendidikan Islam dengan pendekatan kombinasi yaitu pendekatan diakronis sejarah dengan sinkronis ilmu-ilmu sosial yaitu sosiologi dan antropologi dengan memunculkan karakteristik-karakteristiknya dan juga tokoh-tokohnya. Serta yang terakhir penulis mencoba untuk memberikan alternatif-solutif tentang pendekatan yang harus digunakan untuk kajian pendidikan Islam ke depannya.

\section{B. Pendidikan Islam dalam Pendekatan Multidisipliner 1. Pendidikan dan Pendidikan Islam (Sebuah Definisi)}

Sebelum membahas lebih detail tentang pendidikan Islam dalam pendekatan multidisipliner yaitu dari pendekatan historis (sejarah), antropologi, dan sosiologi, maka penulis sedikit memaparkan tentang definisi pendidikan dan pendidikan Islam. Dengan pendefinisian tersebut akan tercipta satu konsepsi dan persepsi tentang pendidikan dan pendidikan Islam yang intepretable, karena tergantung penekanan pendefinisiannya. Hal pertama dilakukan dalam memberi definisi tersebut adalah memaparkan definisi dari tokoh-tokoh yang selanjutnya penulis menyimpulkan pendapat para tokoh tersebut untuk mendapatkan definisi dari pendidikan Islam sebagai tema sentral dari pembahasan ini.

Menurut Crow and crow, seperti yang dikutip oleh Fuad Ihsan (2005: 4) dalam bukunya "Dasar-Dasar Kependidikan", mengatakan bahwa pendidikan adalah proses yang berisikan berbagai macam kegiatan yang cocok bagi individu untuk kehidupan sosialnya dan membantu meneruskan adat dan budaya serta kelembagaan sosial dari generasi ke generasi. Sedangkan dalam Undang-Undang SISDIKNAS (2003: 2), pendidikan diartikan sebagai usaha sadar dan terencana untuk mewujudkan suasana belajar dan proses 
Vol. II, No. 02, Mei 2014

pembelajaran agar peserta didik secara aktif mengembangkan potensi dirinya untuk memiliki kekuatan spiritual keagamaan, pengendalian diri, kepribadian, kecerdasan, akhlak mulia, serta keterampilan yang diperlukan dirinya, masyarakat, Bangsa dan Negara.

Sedangkan pendidikan Islam menurut Endang Saifuddin Anshori, seperti yang dikutip oleh Azyumardi Azra (2002: 6), adalah proses bimbingan (pimpinan, tuntutan, usulan) oleh subjek didik terhadap perkembangan jiwa (pikiran, perasaan, kemauan, intuisi dan sebagainya) dan raga objek didik dengan bahan-bahan tertentu pada jangka waktu tertentu dan dengan alat perlengkapan yang ada ke arah terciptanya pribadi tertentu disertai evaluasi sesuai dengan ajaran Islam.

Sedangkan Muhammad S. A. Ibrahimy, sebagaimana yang di kutip oleh Syaiful (1999: 10) dalam Laporan Penelitiannya, memberikan definisi bahwa pendidikan Islam adalah: Islamic education in the true sense of learn, is a system of education wich enables a man to lead his life according of the islamic ideology, so that he may easily mould his life accordence with tenets of Islam.

Maka dapat disimpulkan bahwa pendidikan Islam merupakan suatu sistem pendidikan yang membimbing peserta didik pada perkembangan jiwa dan raganya yang berideologi pada ajaran Islam yaitu al-Qur'an dan hadist.

\section{Pendidikan Islam Dalam Pendekatan Sejarah}

Menurut Kuntowijoyo (1995: 17), sejarah merupakan rekonstruksi masa lalu, yaitu merekonstruksi apa saja yang sudah dipikirkan, dikerjakan, dikatakan, dirasakan, dan dialami manusia. Namun, perlu ditegaskan bahwa membangun kembali masa lalu bukan untuk kepentingan masa lalu itu sendiri. Sejarah mempunyai kepentingan masa kini dan, bahkan, untuk masa yang akan datang. Oleh karenanya, orang tidak akan belajar sejarah karena tidak akan ada gunanya. Kenyataannya, sejarah terus di tulis, di semua peradaban dan di sepanjang waktu. Hal ini, sebenarnya cukup menjadi bukti bahwa sejarah itu sangat urgen. ${ }^{3}$

\footnotetext{
${ }^{3}$ Dalam hal ini, Kuntowijoyo menjelaskan bahwa sejarah mempunyai nilai guna intrinsik: (1) sejarah sebagai ilmu, (2) sejarah sebagai cara mengetahui masa lampau, (3) sejarah sebagai penyataan pendapat, dan (4) sejarah sebagai profesi, sedangkan nilai guna ekstrinsik, yakni sebagai pendidikan: (1) moral, (2) Penalaran, (3) politik, (4) kebijakan, (5) perubahan, (6) masa depan, (7) keindahan, dan (8) ilmu bantu, selain berfungsi sebagai (9) latar belakang (10) rujukan, dan (11) bukti (lihat dalam Kuntowijoyo, 1995: 19).
} 
Namun dalam sejarah konvensional yang banyak dideskripsikan adalah pengalaman manusia yang menyangkut tentang sistem perpolitikan, peperangan dan juga terdistorsi pada tataran bangun jatuhnya suatu kekuasaan seperti dinasti, khilafah atau kerajaan. sebaliknya dalam sejarah harus ada upaya rekonstruksi masa lalu yang berhubungan dengan totalitas pengalaman manusia. Maka dengan konsep tersebut, sejarah mempunyai batas-batas definisi yang longgar dibandingkan dengan definisi-definisi ilmu sosial lainnya. Sejarah dapat didefinisikan dengan politik masa lalu, ekonomi masa lalu, masyarakat masa lalu ataupun sebagai sains atau ilmu pengetahuan masa lalu.

Namun kebanyakan sejarah sosial -khususnya tentang pendidikanmasih berkutat pada pembahasan tentang sejarah ekonomi yang menyangkut tentang aspek kehidupan manusia. Dalam hal ini, Kuntowijoyo (2003: 39) berpendapat bahwa sejarah sosial mempunyai hubungan erat dengan sejarah ekonomi, sehingga menjadi semacam sejarah sosial ekonomi. Walaupun demikian, ada beberapa tema yang berkaitan dengan sejarah sosial. Ada pengertian bahwa sejarah sosial yang mencakup berbagai aspek kehidupan manusia kecuali masalah-masalah berkaitan masalah politik (Nor Huda, 2007: 18).

Dari deskripsi di atas, kita bisa memetakan definisi dari sejarah pendidikan atau terspesifikasi pada pendidikan Islam. Substansi dan tekanan dalam sejarah pendidikan itu bermacam-macam tergantung kepada maksud dari kajian itu: mulai dari tradisi pemikiran dan para pemikir besar dalam pendidikan, tradisi nasional, sistem pendidikan beserta komponen-komponennya, sampai pada pendidikan dalam hubungannya dengan sejumlah elemen problematis dalam perubahan sosial atau kestabilan, termasuk keagamaan, ilmu pengetahuan (sains), ekonomi, dan gerakan-gerakan sosial. Sehubungan dengan itu semua John E. Talbott (1992: 210) mengungkapkan bahwa sejarah pendidikan erat kaitannya dengan sejarah intelektual dan sejarah sosial.

Maka dalam pengkajian pendidikan Islam melalui pendekatan sejarah, banyak para pakar pendidikan Islam menggunakan pola pemikiran rasionalistik-fenomenologik untuk memahami pesan sejarah pendidikan Islam. Seperti halnya dengan Ibnu Khaldun yang kapasitasnya sebagai seorang pemikir. Ibnu Khaldun memiliki watak yang luar biasa yang 
Vol. II, No. 02, Mei 2014

walaupun kadang terasa kurang baik. Dalam hal ini Muhammad Abdullah Enan melukiskan kepribadian Ibnu Khaldun yang istimewa itu dengan mencoba memperlihatkan ciri psikologik Ibnu Khaldun, walaupun diakuinya secara moral ini tidak selalu sesuai. Menurutnya ia melihat dalam diri Ibnu Khaldun terdapat sifat angkuh dan egoisme, penuh ambisi, tidak menentu dan kurang memiliki rasa terima kasih. Namun di samping sifatsifatnya yang tersebut di atas dia juga mempunyai sifat pemberani, tabah dan kuat, teguh pendirian serta tahan uji. Di samping memiliki intelegensi yang tinggi, cerdas, berpandangan jauh dan pandai berpuisi (Muhammad Abdullah Enan, 1995: 242).

Menurut beberapa ahli, Ibnu Khaldun dalam proses pemikirannya mengalami percampuran yang unik, yaitu antara dua tokoh yang saling bertolak belakang, yaitu Al-Ghazali dan Ibnu Rusyd (Juwariyah, 2004: 76). AlGhazali dan Ibnu Rusyd bertentangan dalam bidang filsafat. Ibnu Rusyd adalah pengikut Aristoteles yang setia, sedangkan Al-Ghazali adalah penentang filsafat Aristoteles yang gigih. Ibnu Khaldun adalah pengikut AlGhazali dalam permusuhannya melawan logika Aristoteles, dan pengikut Ibnu Rusyd dalam usahanya mempengaruhi massa. Ibnu Khaldun adalah satu-satunya sarjana muslim waktu itu yang menyadari arti pentingnya praduga dan kategori dalam pemikiran untuk menyelesaikan perdebatanperdebatan intelektual. Barangkali karena itulah seperti anggapan Fuad Baali (1999: 49) bahwa Ibnu Khaldun membangun suatu bentuk logika baru yang realistik, sebagai upayanya untuk mengganti logika idealistik Aristoteles yang berpola paternalistik-absolutistik-spiritualistik. Sedangkan logika realistik Ibnu Khaldun ini berpola pikir relatifistik-temporalistik-materialistik.

Dengan berpola pikir seperti itulah Ibnu Khaldun mengamati dan menganalisa gejala-gejala sosial beserta sejarahnya, termasuk juga aspek pendidikan, yang pada akhirnya tercipta suatu teori kemasyarakatan yang modern. Karya-karya intelektual Ibnu Khaldun adalah sebagai berikut:

a. Kitab Muqaddimah, yang merupakan buku pertama dari kitab al-'Ibar, yang terdiri dari bagian muqaddimah (pengantar). Buku pengantar yang panjang inilah yang merupakan inti dari seluruh persoalan, dan buku tersebut pulalah yang mengangkat nama Ibnu Khaldun menjadi begitu harum. Adapun tema muqaddimah ini adalah gejala-gejala sosial dan sejarahnya. 
b. Kitab al-'Tbar, wa Diwan al-Mubtada' wa al-Khabar, fi Ayyam al-'Arab wa al-'Ajam wa al-Barbar, wa man Asharuhum min dzawi as-Sulthani al'Akbar. (Kitab Pelajaran dan Arsip Sejarah Zaman Permulaan dan Zaman Akhir yang mencakup Peristiwa Politik Mengenai Orangorang Arab, Non-Arab, dan Barbar, serta Raja-raja Besar yang Semasa dengan Mereka), yang kemudian terkenal dengan kitab 'Ibar, yang terdiri dari tiga buku: Buku pertama, adalah sebagai kitab Muqaddimah, atau jilid pertama yang berisi tentang: Masyarakat dan ciri-cirinya yang hakiki, yaitu pemerintahan, kekuasaan, pencaharian, penghidupan, keahlian-keahlian dan ilmu pengetahuan dengan segala sebab dan alasan-alasannya. Buku kedua terdiri dari empat jilid, yaitu jilid kedua, ketiga, keempat, dan kelima, yang menguraikan tentang sejarah bangsa Arab, generasi-generasi mereka serta dinasti-dinasti mereka. Di samping itu juga mengandung ulasan tentang bangsa-bangsa terkenal dan negara yang sezaman dengan mereka, seperti bangsa Syiria, Persia, Yahudi (Israel), Yunani, Romawi, Turki dan Franka (orang-orang Eropa). Kemudian Buku Ketiga terdiri dari dua jilid yaitu jilid keenam dan ketujuh, yang berisi tentang sejarah bahasa Barbar dan Zanata yang merupakan bagian dari mereka, khususnya kerajaan dan negara-negara Maghribi (Afrika Utara).

c. Kitab al-Ta'rif bi Ibnu Khaldun wa Rihlatuhu Syarqon wa Ghorban atau disebut $a l-T a^{\prime}$ rif, dan oleh orang-orang Barat disebut dengan Autobiografi, merupakan bagian terakhir dari kitab al-'Tlbar yang berisi tentang beberapa bab mengenai kehidupan Ibnu Khaldun. Dia menulis autobiografinya secara sistematis dengan menggunakan metode ilmiah, karena terpisah dalam bab-bab, tapi saling berhubungan antara satu dengan yang lain (lihat dalam Fuad Baali, 1999: 49-55).

\section{Pendidikan Islam dalam Pendekatan Antropologi}

Antropologi adalah suatu ilmu yang memahami sifat-sifat semua jenis manusia secara lebih komprehensif (Williiam A. Haviland, terj. RG Soekarjo, 1988: 3). Antropologi pertama kali dipergunakan oleh kaum Misionaris dalam rangka penyebaran agama Nasrani dan bersamaan dengan itu pula berlangsung sistem penjajahan terhadap negara-negara di luar Eropa. Pada era dewasa ini, antropologi dipergunakan sebagai suatu hal untuk 
Vol. II, No. 02, Mei 2014

kepentingan kemanusiaan yang lebih luas. Studi antropologi selain untuk kepentingan pengembangan ilmu itu sendiri, di negara-negara yang masuk dalam kategori Negara ketiga (Negara berkembang) sangat urgen sebagai "pisau analisis" untuk pengambilan kebijakan (policy) dalam rangka pembangunan dan pengembangan masyarakat.

Sebagai suatu disiplin ilmu yang cakupan studinya cukup luas, maka tidak ada seorang ahli antropologi yang mampu menelaah dan menguasai antropologi secara sempurna dan global. Sehingga, antropologi terfregmentasi menjadi beberapa bagian yang masing-masing ahli antropologi mengkhususkan dirinya pada spesialisasi bidangnya masing-masing. Pada dataran ini, antropologi menjadi amat plural, sesuai dengan perkembangan ahli-ahli antropologi dalam mengarahkan studinya untuk lebih memahami sifat-sifat dan hajat hidup manusia secara lebih komprehensif. Dan hubungan dengan ini pula, ada bermacam-macam antropologi seperti antropologi ekonomi, antropologi politik, antropologi kebudayaan, antropologi agama, antropologi pendidikan, antropologi perkotaan, dan lain sebagainya. Grace de Raguna, seorang filsuf wanita pada tahun 1941, menyampaikan pidatonya di hadapan American Philosophical Association Eastern Division, bahwa antropologi telah memberi lebih banyak kejelasan tentang sifat manusia daripada semua pemikiran filsuf atau studi para ilmuwan di laboratoriumnya (Williiam A. Haviland, terj. RGSoekarjo, 1988: 5).

Dan dalam studi kependidikan yang dikaji melalui pendekatan antropologi, maka kajian tersebut masuk dalam sub antropologi yang bias dikenal menjadi antropologi pendidikan. Artinya apabila antropologi pendidikan dimunculkan sebagai suatu materi kajian, maka yang objek di kajiannya adalah penggunaan teori-teori dan metode yang digunakan oleh para antropolog serta pengetahuan yang diperoleh khususnya yang berhubungan dengan kebutuhan manusia atau masyarakat. Dengan demikian, kajian materi antropologi pendidikan, bukan bertujuan menghasilkan ahli-ahli antropologi melainkan menambah wawasan ilmu pengetahuan tentang pendidikan melalui perspektif antropologi. Meskipun berkemungkinan ada yang menjadi antropolog pendidikan setelah memperoleh wawasan pengetahuan dari mengkaji antropologi pendidikan.

Pertanyaannya kemudian adalah bagaimana kedudukan antropologi pendidikan sebagai sebuah disiplin studi yang tergolong baru di tambah kata 
"Islam" sehingga menjadi "antropologi pendidikan Islam". Hal ini telah menjadi sorotan para ahli pendidikan Islam, bahwa hal tersebut merupakan suatu langkah yang ada relevansinya dengan isu-isu Islamisasi ilmu pengetahuan. ${ }^{4}$ Dengan pola itu, maka antropologi pendidikan Islam tentunya harus dikategorikan "sama" dengan ekonomi Islam. Artinya bagaimana bangunan keilmuan yang ditonjolkan dalam ekonomi Islam muncul juga dalam antropologi pendidikan Islam, sehingga muncul pula kaidah-kaidah keilmiahannya yang bersumber dari kitab suci Al-Qur'an dan dari As Sunah. Seperti dalam ekonomi Islam (juga Hukum Islam) yang sejak awal pertumbuhannya telah diberi contoh oleh Nabi Muhammad dan diteruskan oleh para sahabat. Maka antropologi pendidikan Islam, kaidah-kaidah keilmiahannya harus juga bersumber atau didasarkan pada Al-Qur'an dan As Sunah. Akan tetapi dalam sejarah kebudayaan Islam belum ada pengakuan terhadap tokoh-tokoh atau pelopor antropologi yang diakui dari zaman Nabi Muhammad atau sesudahnya (lihat dalam Abd. Shomad di www.uinsuka.info/ejurnal/selayang_pandang_tentang_antropologi_pendidikan_islam).

Karakteristik dari antropologi pendidikan Islam adalah terletak pada sasaran kajiannya yang tertuju pada fenomena pemikiran yang berarah balik dengan fenomena Pendidikan Agama Islam (PAI). Pendidikan Agama Islam arahnya dari atas ke bawah, artinya sesuatu yang dilakukan berupa upaya agar wahyu dan ajaran Islam dapat dijadikan pandangan hidup anak didik (manusia). Sedangkan antropologi pendidikan Islam dari bawah ke atas, mempunyai sesuatu yang diupayakan dalam mendidik anak, agar anak dapat membangun pandangan hidup berdasarkan pengalaman agamanya bagi kemampuannya untuk menghadapi lingkungan (lihat dalam Abd. Shomad di www.uin-suka.info/ejurnal/selayang_pandang_tentang_antropologi_pendidikan_islam). Masalah ilmiah yang mendasar pada Pendidikan Agama Islam adalah berpusat pada bagaimana (metode) cara yang seharusnya

${ }^{4}$ Bahkan dalam pengkajian agama yang dikaji dari aspek antropologi telah banyak digunakan dalam rangka menemukan atau mendekati eksistensi kebenaran dari fenomena agama. Bahkan sekarang ini ada kecenderungan untuk melihat Islam secara menyeluruh dengan menonjolkan ciri-ciri Islam lokal. Kajian semacam Marshal Hodgson yang mencoba menggabungkan perjalanan pergumulan Islam dengan budaya maupun peradaban lokal menunjukkan suatu hasil yang memuaskan. Buku The Venture of Islam, tidak saja menghasilkan sebuah peta besar keberagaman Islam, tetapi juga merupakan tantangan tersendiri bagi pengamat Islam untuk menerjemahkan makna keberagaman itu. Di lain pihak, buku itu menyisakan banyak "homework" untuk kita semua bagaimana mengembangkan pemahaman dan kajian Islam di tingkat lokal untuk melihat keragaman dan kekayaan Islam lokal. 
Vol. II, No. 02, Mei 2014

dilakukan. Sedangkan masalah yang mendasar pada antropologi pendidikan Islam adalah berpusat pada pengalaman apa yang ditemui.

Ibnu Sina, yang kita kenal sebagai tokoh kedokteran dalam dunia Islam ternyata juga merupakan seorang pemerhati pendidikan anak usia dini yang merupakan pengalaman pertama anak. Dalam kitabnya al-Siyasah, Ibnu Sina banyak memaparkan tentang pentingnya pendidikan usia dini yang dimulai dengan pemberian "nama yang baik" dan diteruskan dengan membiasakan berperilaku, berucap-kata, dan berpenampilan yang baik serta pujian dan hukuman dalam mendidikkan anak. Dan juga yang paling urgen adalah penanaman nilai-nilai sosial pada anak seperti rasa belas kasihan (confession) dan empati terhadap orang lain (Imam Tholkhah dan Ahmad Barizi, 2004: 253-257).

Kaya-karya Ibnu Sina yang cukup terkenal antara lain:

a. Al-Syifa', sebuah karya filsafat.

b. Fi Aqsam ‘Ulum al-Aqliyyah, sebuah kitab logika.

c. Al-Siyasah

d. Mabhats 'an al-Quwa al-Nafsaniyyah

e. Dan lain sebagainya.

\section{Pendidikan Islam Dalam Pendekatan Sosiologi}

Sosiologi merupakan suatu disiplin ilmu sosial yang mempelajari tentang masyarakat. ${ }^{5}$ Masyarakat, menurut Emile Durkheim seperti yang dikutip oleh Ishomuddin (1997: 9), itu terdiri atas kelompok-kelompok manusia yang hidup secara kolektif, kehidupan tersebut memerlukan interaksi antara satu dengan yang lain, baik secara individu maupun kelompok. Sedangkan seorang sosiolog yaitu Alvin Bertrand, seperti yang dikutip oleh Bahrein T. Sugihen (1996: 4), memandang sosiologi sebagai suatu ilmu yang mempelajari dan menjelaskan tentang hubungan antar manusia (human relationship). Dengan demikian, secara esensial sosiologi adalah ilmu yang mempelajari hubungan manusia dalam hidup di tengah-tengah masyarakat. Unsur utama dalam sosiologi adalah interaksi, masyarakat, proses dan kehidupan manusia.

\footnotetext{
${ }^{5}$ Menurut Aguste Comte, yang dinamakan masyarakat adalah kelompok-kelompok makhluk hidup dengan realitas-realitas baru yang berkembang menurut hokum-hukumnya sendiri dan berkembang menurut pola perkembangannya sendiri (lihat dalam Abdul Syani, 1992: 4).
} 
Dalam prakteknya sosiologi seperti halnya ilmu sosial lainnya telah banyak diterapkan dalam berbagai bidang salah satunya adalah dalam pertanian sehingga muncul ilmu terapan sosiologi yaitu sosiologi pertanian. Oleh sebab itu, sosiologi juga diterapkan dalam pendidikan yang muncul dalam ilmu terapan yaitu sosiologi pendidikan yang oleh Ary H. Gunawan (2000: 45) didefinisikan sebagai sosiologi yang diterapkan untuk memecahkan masalah-masalah pendidikan yang fundamental. Sedangkan oleh S. Nasution (dalam Ary H. Gunawan, 2000: 3), sosiologi pendidikan diartikan sebagai ilmu yang berusaha untuk mengetahui cara-cara mengendalikan proses pendidikan untuk mengembangkan kepribadian individu agar lebih baik.

Titik tolak dari pandangan ini ialah prioritas kepada kebutuhan masyarakat dan bukan kepada kebutuhan individu. Peserta didik adalah anggota masyarakat. Dalam sejarah perkembangan manusia kita lihat bahwa tuntutan masyarakat tidak selalu etis. Versi yang lain dari pandangan ini ialah developmentalisme. Proses pendidikan diarahkan kepada pencapaian targettarget tersebut dan tidak jarang nilai-nilai kemanusiaan disubordinasikan untuk mencapai target pembangunan. Pengalaman pembangunan Indonesia selama Orde Baru telah mengarah kepada paham developmentalisme yang menekan kepada pencapaian pertumbuhan yang tinggi, target pemberantasan buta huruf, target pelaksanaan wajib belajar 9 dan 12 tahun.

Salah satu pandangan sosiologisme yang sangat populer adalah konsiensialisme yang dikumandangkan oleh ahli pikir pendidikan terkenal Paulo Freire, seorang Doktor sejarah dan filsafat pendidikan di Universitas Recife, Brasil dan juga seorang praktisi pendidikan yang banyak menggagas pendidikan liberatif (A. Malik Fajar dalam Imam Tholkhah dan Ahmad Barizi, 2004: 1-2). Pendidikan yang dikumandangkan oleh Freire ini yang juga dikenal sebagai pendidikan pembebasan pendidikan adalah proses pembebasan. Konsiensialisme yang dikumandangkan Freire merupakan suatu pandangan pendidikan yang sangat mempunyai kadar politis karena dihubungkan dengan situasi kehidupan politik terutama di negara-negara Amerika Latin. Paulo Freire di dalam pendidikan pembebasan melihat fungsi atau hakikat pendidikan sebagai pembebasan manusia dari berbagai penindasan. Sekolah adalah lembaga sosial yang pada umumnya mempresentasi kekuatan-kekuatan sosial 
Vol. II, No. 02, Mei 2014

politik yang ada agar menjaga status quo hukum membebaskan manusia dari tirani kekuasaan. Status qua atau di dalam istilah Paulo Freire "kapitalisme yang licik". Sekolah harus berfungsi membangkitkan kesadaran bahwa manusia adalah bebas.

Karya-karya Paulo Freire ini diantaranya adalah: Paedagogy of The Oppressed (1970), Cultural Action of Freedom (1970), Education for Critical Consiousness (1973), Education: The Practice of Freedom (1976), The Politics of Education: Culture, Power, and Liberation (1980) dan juga telah banyak diterjemahkan ke dalam bahasa Indonesia seperti Pendidikan Sebagai Praktek Pembebasan (Jakarta: Gramedia, 1980) dan Pendidikan Kaum Tertindas (Jakarta: LP3ES, 1991), (lihat dalam A. Malik Fajar dalam Imam Tholkhah dan Ahmad Barizi, 2004: 1-3).

\section{Konseptualisasi}

Hakikat pendidikan itu dapat dikategorisasikan dalam dua pendapat yaitu pendekatan epistemologis dan pendekatan ontologi atau metafisik. Kedua pendekatan tersebut tentunya dapat melahirkan jawaban yang berbeda-beda mengenai apakah hakikat pendidikan itu sendiri, artinya dengan pendekatan yang berbeda-beda akan melahirkan penekanan yang berbeda-beda pula dalam mendekati satu objek.

Dalam epistemologi pendidikan yang menjadi masalah adalah akar atau kerangka ilmu pendidikan sebagai ilmu. Pendekatan tersebut mencari makna pendidikan sebagai ilmu yaitu mempunyai objek yang akan merupakan dasar analisis yang akan membangun ilmu pengetahuan yang disebut ilmu pendidikan. Dari sudut pandang tersebut, pendidikan dilihat sebagai sesuatu proses yang intern dalam konsep manusia. Artinya manusia hanya dapat dimanusiakan melalui proses pendidikan.

Dalam konsep epistemologi pendidikan, perbedaan materi pelajaran dan perbedaan sosial-budaya-ekonomi-politik yang dijalani peserta didik dan pendidik itu hanya merupakan manifestasi bentuk luarnya, namun secara substansial sama. Dasar-dasar inilah yang merupakan dasar-dasar integrated curriculum. Sedangkan AM. Saefuddin (1993: 114) dalam bukunya "Desekularisasi Pemikiran: Landasan Islamisasi" mengatakan bahwa integrated 
curriculum, di sini bisa dimenifestasikan berupa pelarutan dua hal yang berbeda untuk dipadukan baik secara substantif maupun normatif yang hasilnya sudah tidak bias dibeda-bedakan jenisnya, ataupun pencampuran di mana hasil perpaduannya masih bias dibedakan baik secara substantif maupun normatif.

Berbeda hal dengan Jerome Bruner (1994: 59) dalam bukunya "The Process of Education" yang mengatakan bahwa "pelarutan" di sini berarti "integrated curriculum", sedangkan "pencampuran" berarti "correlated curriculum". Artinya dalam upaya pembenahan pendidikan tersebut banyak hal yang perlu direkonstruksi atau bahkan di dekonstruksi untuk menemukan suatu tatanan pendidikan yang lebih baik dan sesuai dengan perkembangan zaman. Oleh sebab itu, perlu adanya pendekatan baru untuk menemukan hakikat pendidikan yang koheren dengan perubahan zaman dan sesuai dengan pola perkembangan peserta didik. Maka, penulis mencoba untuk memetakan dan memberikan pendekatan baru dalam meneropong pendidikan Islam sebagai pendidikan alternatif-solutif.

Seperti yang telah dijelaskan di atas, berbagai pendapat mengenai hakikat pendidikan dapat digolongkan atas dua kelompok besar yaitu: Pendekatan reduksionisme dan holistik-integratif. Pendekatan reduksionisme melihat proses pendidikan peserta didik dan keseluruhan termasuk lembagalembaga pendidikan, menampilkan pandangan ontologis maupun metafisis tertentu mengenai hakikat pendidikan. Teori-teori tersebut satu persatu sifatnya mungkin mendalam secara vertikal namun tidak melebar secara horizontal.

Peserta didik, anak manusia, tidak hidup secara terisolasi tetapi dia hidup dan berkembang di dalam suatu masyarakat tertentu, yang berbudaya, yang mempunyai visi terhadap kehidupan di masa depan, termasuk kehidupan pasca kehidupan. Oleh sebab itulah, M Kamal Hasan, sebagaimana di kutip Samsul Nizar (2001: 93), memberikan pengertian bahwa pendidikan Islam adalah "suatu proses yang komprehensif dari pengembangan kepribadian manusia secara keseluruhan, yang meliputi intelektual, spiritual, emosi, dan fisik.

Pendekatan reduksionisme terhadap hakikat pendidikan, maka dirumuskan suatu pengertian operasional mengenai hakikat pendidikan. 
Vol. II, No. 02, Mei 2014

Hakikat pendidikan adalah suatu proses menumbuhkembangkan eksistensi peserta didik yang memasyarakat, membudaya, dalam tata kehidupan yang berdimensi lokal, nasional dan global. Rumusan operasional mengenai hakikat pendidikan tersebut di atas mempunyai komponen-komponen sebagai berikut:

a. Pendidikan Merupakan Suatu Proses Berkesinambungan

Proses berkesinambungan yang terus menerus dalam arti adanya interaksi dalam lingkungannya. Lingkungan tersebut berupa lingkungan manusia, lingkungan sosial, lingkungan budayanya dan ekologinya. Sehingga dalam proses pendidikan adalah proses penyelamatan kehidupan sosial dan penyelamatan lingkungan yang memberikan jaminan hidup yang berkesinambungan. Proses pendidikan yang berkesinambungan berarti bahwa manusia tidak pernah akan selesai.

b. Proses pendidikan Berarti Menumbuhkembangkan Eksistensi Manusia

Eksistensi manusia merupakan suatu keberadaan yang interaktifinterkonektif. Eksistensi manusia harus mempunyai arti dengan hubungan sesama manusia baik yang dekat maupun dalam ruang lingkup yang semakin luas dengan sesama manusia di dalam planet bumi ini. Proses pendidikan bukan hanya mempunyai dimensi lokal tetapi juga berdimensi nasional dan global.

c. Eksistensi Manusia Yang Memasyarakat

Proses pendidikan adalah proses mewujudkan eksistensi manusia yang memasyarakat. J. Dewey, seperti yang dikutip oleh Sri Widayati (2002: 10), mengatakan bahwa tujuan pendidikan tidak berada di luar proses pendidikan itu tetapi di dalam pendidikan sendiri karena sekolah adalah bagian dari masyarakat itu sendiri. Apabila pendidikan diletakkan dalam tempat yang sebenarnya maka ialah sebagai bagian yang tak terpisahkan dari kehidupan manusia yang pada dasarnya adalah kehidupan bermoral.

d. Proses Pendidikan Dalam Masyarakat Yang Membudaya

Inti dari kehidupan bermasyarakat adalah nilai-nilai. Nilai-nilai tersebut perlu dihayati, dilestarikan, dikembangkan dan dilaksanakan oleh 
seluruh anggota masyarakatnya. Penghayatan dan pelaksanaan nilai-nilai yang hidup, keteraturan dan disiplin para anggotanya. Tanpa keteraturan dan disiplin maka suatu kesatuan hidup akan bubar dengan sendirinya dan berarti pula matinya suatu kebudayaan.

e. Proses Bermasyarakat Dan Membudaya Mempunyai DimensiDimensi Waktu Dan Ruang

Dengan dimensi waktu, proses tersebut mempunyai aspek-aspek historisitas, kekinian dan visi masa depan. Aspek historisitas berarti bahwa suatu masyarakat telah berkembang di dalam proses waktu, yang menyejarah, berarti bahwa kekuatan-kekuatan historis telah menumpuk dan berasimilasi di dalam suatu proses kebudayaan. Proses pendidikan adalah proses pembudayaan, dan proses pembudayaan adalah proses pendidikan. Menggugurkan pendidikan dari proses pembudayaan merupakan alienasi dari hakikat manusia dan dengan demikian alienasi dari proses humanisasi. Alienasi proses pendidikan dari kebudayaan berarti menjauhkan pendidikan dari perwujudan nilai-nilai moral di dalam kehidupan manusia.

Komponen-komponen hakikat pendidikan itu harus diintegrasikan dalam kurikulum pendidikan Islam sebagai langkah awal membangun paradigma pendekatan holistic-integratif. Kurikulum yang oleh J. Galen Saylor dan William M. Alexander dalam bukunya Curriculum Planning For Better Teaching And Learning, menjelaskan arti kurikulum dengan "The curriculum is the sum total of schools efforts to influence learning, whether instruksional the clasroom, on the playgroup, or out of school" (lihat dalamS. Nasution, 1999: 4). Ini artinya sesuatu di luar konteks pembelajaran atau konstek sekolah yang masih mempengaruhi atau membawa implikasi logis-konstruktif pada peserta didik dapat kita asumsikan bahwa itu adalah kurikulum. Dan segala sesuatu yang berimplikasi pada peserta didik tersebut harus teraktualisasikan dalam bentuk aplikatif-kongkrit.

Momentum pada aplikatif-kongkrit akan memunculkan learning by doing, artinya kurikulum yang sebagai the sum total of schools tidak pada hanya ranah kognitif, tetapi juga pada ranah afektif dan psikomotorik. Dan pada tataran ini juga suatu kurikulum berdiri pada platform universal, artinya kurikulum terkonstruksi dengan konteks makro atau global tidak pada konteks- 
Vol. II, No. 02, Mei 2014

spesifik ataupun sebaliknya. Hal ini akan berimplikasi pada dualitas output, sebab ketika konteks diglobalkan atau dispesifikan maka akan memunculkan suatu sikap pesimistik-degradasi yang memiskinkan kreativitas makro atau mikro dan konstruk kehidupan yang destruktif. Hal ini tidak hanya tertuju pada dirinya sendiri tetapi juga pada orang lain dan lingkungan sekitarnya.

Pada abad pertengahan tepatnya pada abad ke-XI di Madrazah Nizamiyyah terjadi penspesifikan kurikulum yang hanya menekankan pada supremasi figh an sich. Semua cabang ilmu agama yang lain diperkenalkan dalam rangka menopang superioritas dan penjabaran hukum Islam. Figh oriented education adalah ciri yang menonjol pada masa itu sehingga Madrasah Nizamiyyah benar-benar menjadi model pendidikan yang dikotomi (Abdurrahman Mas'ud, 2002: 110). Hal tersebut membuktikan bahwa spesifikasi kurikulum pada hal-hal yang mikro akan membawa konsekuensi atau berdampak pada sub-sub lainnya bahkan akan mengkonstruk paradigma dan mainstream dikotomik.

Namun dalam konteks pendidikan Islam sendiri, kurikulum yang merupakan planning of learning dan dalam tataran idea terbingkai (frame) dalam integritas antara hal-hal yang profan dan yang sakral. Bahkan hal tersebut telah menjadi tujuan pendidikan Islam untuk mengkonstruk manusia menjadi manusia bertakwa, manusia yang dapat mencapai al-falaah (Soeroyo, 1994: 43). Tetapi kurikulum Islam belum mampu untuk mengkonstruk dan menelurkan manusia yang mampu mengintegritaskan ilmu profan yang sekuleristik-rasionalistik dengan ilmu sakralistik yang cenderung pada taken for granted dan wahyuistik (kebenaran mutlak). Performa kurikulum Islam yang memegang konsep continue education dan life long education terbentur dengan problem klasik yang tetap aktual karena masih sering segar dipersoalkan oleh para pakar pendidikan (Islam) dan telah menjadi public image bahwa adanya dikotomik dalam dunia pendidikan Islam. Problema dikotomik ini tercover dalam clasical education paradigm, di mana konsep paradigma pendidikan klasikal membutuhkan re-education atau bahkan deeducation pada era kontemporer-globalisasi. Problema dikotomik mendorong pada dualitas fundamental dan memfregmentasi atau menkristalisasi 
paradigma menjadi dua wilayah yaitu antara konservatif-status quo dan liberalkonstektual. 6

Pada liberal-konstektual menurut pandangan A.C. Ornstein dan Daniel U. Levine, menancapkan pada pemikiran dan pendidikan Yunani, Romawi, Arabic Learning, Kontibusi Medieval, Kontribusi Renaissance, Reformasi Religi dan gerakan The Age of Reason (Roihan Achwan, 1998: 66). Bertolak pada ranah optimistik-fungsionalistik itulah, liberalis-kontekstual mengembang pendidikan sesuai dengan kebutuhan era (needs era). Maka dialektika antara das sollen dan das sein, antara realitas dan idea memunculkan metodologi supremacy of reason. Kemudian ketika tuntutan era menghendaki manusia instan dengan human resource yang tinggi dan juga pada capability, pendidikan liberal-konstektual mampu untuk menghadirkan dan menyajikannya. Akan tetapi karakteristik pendidikan liberalis-kontekstual adalah sebagai refleksi pemikiran dan kultur abad XVIII-XIX yang ditandai dengan isolirnya terhadap agama, sekularisme negara, materialism, penyangkalan terhadap wahyu dan penghapusan nilai-nilai etika yang kemudian digantikan dengan pragmatism (Amrullah Achmad, dalam Azyumardi Azra, 2002: 86). Materialisme akan memunculkan sikap hedonistik dan konsekuensinya sikap itu akan melahirkan sikap rasionalistik-empiristik tanpa ada landasan pada humanis-teosentris.

Seharusnya sikap rasionalistik- empiristik dikembangkan dalam frame etiket yang representatif untuk membangun peradaban manusia. Kalau kita sedikit membaca gerakan the age of enlightenment yang diprosesi melalui reason and scientific method dengan konsistensi kausalis dogmatisasi rasio, maka intuition dan heart dikalahkan oleh supremacy of reason dengan akal payungnya. Reason, brain, dan heart memiliki posisi determinan tanpa ada yang dilebihkan antara position yang satu dengan yang lainnya. Menurut teori dari Muhammad Iqbal

\footnotetext{
${ }^{6}$ Dua istilah tersebut adalah konstruksi dari penulis sendiri. asumsi penulis berkenaan dengan istilah konservatif-status quo bahwa pendidikan Islam masih berpatokan pada transfer of knowledga an sich tanpa mengembangkan pada tataran metodologi ilmu pengetahuan. Ini diindikasikan dengan masih berpegang teguhnya para sarjana pendidikan Islam pada nilai klasikalnya, walaupun pada hari ini paradigma tersebut ada pergeseran. Sedangkan istilah liberalkonstektual adalah pendidikan liberalis-kontekstual yang selalu mengikuti alur ruang dan waktu atau dalam bahasa lain pendidikan liberalis-kontekstual terkonstruk sesuai dengan tuntutan era.
} 
Vol. II, No. 02, Mei 2014

bahwa knowledge is a progressive ideal starting from the knowledge provided by sense; perseption and ending with knowledge provided by heart (Roihan Achwan, 1998: 71).

Persoalannya adalah karakteristik pendidikan liberalis-kontekstual yang mengedepankan reason daripada intuition. Sedangkan fungsionalisasi instrumen-instrumen yang dimiliki manusia itu untuk mengungkapkan halhal di luar dirinya atau nomena (metafisika) ada pada batas liminitas. Maka energial untuk dapat memberikan kontribusi pada manusia sendiri atau pada peradabannya hanya sebatas liminitas-parsialis. Ketidakmampuan manusia untuk mendeduktifkan dan menginduktifkan penjelajahannya terhadap nomena secara holistik-komprehensif membutuhkan kurikulum atau planning of learning yang berdiferensiasi qur'anik dan sunnatik. Dengan landasan itu nilai-nilai pendidikan yang terancang dalam kurikulum dapat dijadikan sebagai way oflife yang diyakini sebagai representasi dari kebenaran.

Konservatif-status quo mampu untuk menjawab persoalan-persoalan yang membutuhkan aspek keseimbangan antara reason dan intuition, sebab konservatif-status quo merupakan representasi dari planning of learning yang berdiferensial qur'anik dan sunnatik. Tetapi dengan metodologi klasiknya konservatif-status qou belum mampu atau bahkan tidak akan pernah melahirkan manusia instans yang mempunyai human resource dan capability yang tinggi. All round living mampu dihadirkan pada kehidupan aktual manusia dan mengembangkan aspek kreatif kehidupan sebagai suatu uji coba atas keberhasilan suatu lembaga sehingga manusia mampu berkembang dalam kemampuannya yang aktual untuk aktif memikirkan hal-hal yang baik untuk diaktualisasikan (M. Arifin, 1987: 95). Itu seharusnya yang disiapkan atau yang harus mampu diberikan oleh kurikulum untuk mencapai tujuan (goal) pendidikan yang mempunyai sifat integrated dan komperhensif, mencakup ilmu agama dan ilmu umum. Maka ketika sifat integreted dan komperhensif mampu diwujudkan lahirlah sosok manusia mempunyai The Conscious of God dengan spirit liberating and civilizing.

Ada hal yang urgen, ketika kurikulum diintegritaskan agar gap antara science yang merupakan representasi dari liberalis-kontektualis dengan science relegius dari kubu konservatif-status quo tidak terlalu mengangga lebar. Fenomena antara science dan science relegius menunjukkan bahwa science dalam perkembangannya revolutif tetapi sebaliknya science relegius dalam 
perkembangannya evolutif-gradual. Maka penguasaan metodologi dalam suatu ilmu dan juga "dekompartementalisasi"7 merupakan langkah kongkritsolutif. Mengapa hal seperti itu harus dilakukan dengan rancangan dan langkah-langkah konkrit? Yang pertama dan paling fundamental ditarik ke ranah pendidikan sendiri adalah pengkonstrukan mainstream dan paradigma integreted atau pada penguasaan epistemologi non dikotomiknya yang nantinya mampu untuk menciptakan konkrit solution.

Artinya ketika grand teory suatu science telah dikuasai dan mampu mengkreasikan antara rasionalistik-empirinistik dengan planning of learning yang berdeferensial qur'anik dan sunnatik, maka output sekolah yang berbasiskan agama (Islam) tidak dalam frame skeptisistik. Apalagi saat ini man-power dikalahkan oleh man-mind, artinya kemampuan berpikir manusia harus merupakan suatu kemahiran dasar (basic skill). Kemampuan berpikir tidak bisa diharapkan lahir dengan sendirinya sebagai by product dari proses belajar mengajar. Proses pengembangan kemampuan berpikir haruslah merupakan proses yang terintegrasi secara formal dalam struktur proses belajar (Abdurrahman Mas'ud: 2003).

\section{Penutup}

Selama ini studi pendidikan Islam masih menggunakan pendekatan konvensional yang umumnya bersifat diakronis yang kajiannya berpusat pada sejarah dari ide-ide dan tokoh pemikir besar dalam pendidikan, atau sejarah dan sistem pendidikan dan juga lembaga-lembaga, atau sejarah perundang-undangan dan kebijakan umum dalam bidang pendidikan. Sehubungan dengan itu, maka harus ada pendekatan sejarah pendidikan (Islam) baru yang hanya tidak cukup dengan cara-cara diakronis saja. Perlu ada pendekatan metodologis yang baru yaitu dengan pendekatan interdisipliner.

Pendekatan interdisipliner tersebut adalah pendekatan holistikintegratif yang berbasiskan pada komponen-komponen hakikat pendidikan dan pola itu harus diintegrasikan dalam kurikulum pendidikan Islam sebagai langkah awal menuju paradigma pendidikan non dikotomik yang

${ }^{7}$ Meminjam istilah dari penulis makalah Menimbang Kurikulum IAIN: Kasus Kurikulum 1995 dan 1997 yaitu Masykuri Abdillah. www.ditpertais.net/artikel/default.asp 
Vol. II, No. 02, Mei 2014

merupakan anak kandung dari pendekatan konvensional yaitu pendekatan yang bersifat diakronis. Maka ketika sifat integreted dan komperhensif mampu diwujudkan lahirlah sosok manusia yang mempunyai The Conscious of God dengan spirit liberating and civilizing.

\section{Daftar Pustaka}

Abdillah, Masykuri. Makalah: Menimbang Kurikulum IAIN: Kasus Kurikulum 1995 dan 1997, www.ditpertais.net/artikel/default.asp

Achwan, Roihan (1998). Konstruksi Filosofis Pendidikan Islam, dalam Religiusitas IPTEK. Bandung: Pustaka Pelajar.

Amin, Husayn Ahmad (1995). Seratus Tokoh Dalam Islam. Peterj: Bahruddin Fannani, Bandung: PT. Remaja Rosdakarya.

Arifin, M. (1987). Pengantar Filsafat Pendidikan Islam, Jakarta: Rajawali.

Azra, Azyumardi (2002), Pendidikan Islam: Tradisi Dan Modernisasi Menuju Milenium Baru, Jakarta: PT. Logos Wacana Ilmu.

Baali, Fuad dan Ali Wardi (1999). Ibnu Khaldun dan Pola Pemikiran Islam. Peterj: Osman Ralibi, Jakarta: Pustaka Firdaus.

Bruner, Jerome (1994). Proses Pendidikan: Upaya Pembenahan Pendidikan, Jakarta: Bina Rupa Aksara.

Enan, Muhammad Abdullah (1999). Ibnu Khaldun: His Life and Work. Peterj: Muhammad Qodari Arif, Jakarta: Kencana.

Fadjar, A. Malik (1998), Visi Pembaharuan Pendidikan Islam, Jakarta: LP3NI.

Gunawan, Ary H. (2000). Sosiologi Pendidikan: Suatu Analisis Sosiologi Tentang Pelbagai Problem Pendidikan, Jakarta: Reneka Cipta.

Haviland, Williiam A. (1988). Antropologi. Peterj: RG Soekarjo, Jakarta: Erlangga.

Huda, Nor (2007). Islam Nusantara: Sejarah Intelektual Islam di Indonesia, Yogyakarta: Ar-Ruzz Media.

Ihsan, Fuad (2005), Dasar-Dasar Kependidikan, Jakarta: PT. Rineka Cipta.

Ishomuddin (1997). Sosiologi Perspektif Islam, Malang: UMM Press.

Juwariyah (2004). Ibnu Khaldun Dan Pemikirannya Tentang Filsafat Pendidikan. Skripsi Tidak Diterbitkan, Yogyakarta: Universitas Islam Negeri Sunan Kalijaga. 
Tabrani. ZA

Kuntowijoyo (1995). Pengantar Ilmu Sejarah, Yogyakarta: Yayasan Bentang Budaya.

(2003). Metodologi Sejarah, Yogyakarta: Tiara Wacana.

Mas'ud, Abdurrahman (2002), Menggagas Format Pendidikan Nondikotomik: Humanisme Relegius Sebagai Paradigma Pendidikan Islam, Yogyakarta: Gama Media.

(2003), Peran Mahasiswa Dalam Mengembangkan Tradisi Akademik di PTA, Makalah yang dipresentasikan di STAIN Jember pada tanggal 1 September 2003.

Nasution, S. (1999). Asas-Asas Kurikulum, Jakarta: Bumi Aksara.

Nizar, Samsul (2001). Pengantar Dasar-dasar Pendidikan Islam, Gaya Media Pratama.

Saefuddin, AM. (1993). Desekularisasi Pemikiran: Landasan Islamisasi, Bandung: Mizan.

Saiful (1999), Tujuan Pendidikan Islam: Tinjauan Kritis Atas Pemikiran Muhammad 'Athiyah Al-Abrasyi, (Laporan Penelitian), STAIN Jember.

Senge, Peter M. (1994). The Fifth Discipline, Los Angeles: Currency Doubleday.

Shomad, Abd. Selayang Pandang Tentang Antropologi Pendidikan Islam, dalam www.uin-suka.info/ejurnal/selayang_pandang_tentang_antropologipendidikan_islam

Soeroyo (1994). Antisipasi Pendidikan Islam Dan Perubahan Sosial Menjangkau Tahun 2000, dalam Pendidikan Islam di Indonesia: Antara Cita Dan Fakta, Yogyakarta: PT. Tiara Wacana Yogya.

Sugihen, Bahrein T. (1996). Sosiologi Pedesaan: Suatu Pengantar, Jakarta: Raja Grafindo Persada.

Syani, Abdul (1992). Sosiologi Skematika, Teori, Dan Terapan, Bandung: Bumi Aksara.

Talbott, John E. (1992). Education in Intellectual and Social History, dalam Felix Gilbert \&Stephen R. Graubard, ed. Historical Studies Today, New York:W.W.

Tholkhah, Imam dan Ahmad Barizi (2004), Membuka Jendela Pendidikan: Mengurai Benang Tradisi dan Integrasi Keilmuan Pendidikan Islam, Jakarta: PT. Raja Grafindo Persada. 
Vol. II, No. 02, Mei 2014

Undang-Undang SISDIKNAS (Sistem Pendidikan Nasional) Tahun 2003, Jakarta: Sinar Grafika.

Widayati, Sri (2002). Hakikat Pendidikan, (laporan Penelitian), (Malang: Universitas Muhammadiyah Malang), (Laporan Tidak Diterbitkan).

$* * * * *$ 